\title{
Alkohol, andre rusmidler og vold i epidemiologisk perspektiv
}

\author{
Kai Pernanen \\ Statens institutt for alkohol- og narkotikaforskning, Dannevigsveien 10, 0463 Oslo \\ Telefon 22380485 , Telefax 22719059
}

\begin{abstract}
SAMMENDRAG
Den medisinske interessen for vold og voldsskader har økt kraftig i løpet av de siste to tiårene. Det epidemiologiske perspektivet på vold har blitt forsterket og et mer etiologisk og preventivt syn på volden er mere merkbar innenfor sosialmedisinsk forskning. Alkoholen er en etiologisk faktor som har vist seg å være forbundet med vold i de aller fleste samfunn. I denne artikkelen beskrives de viktigste epidemiologiske metodene og funnene i studiet av alkoholens sammenheng med vold. Denne sammenhengen har vist seg ikke å være direkte, men er avhengig av en rekke andre faktorer, og noen forskjellige typer av kausal avhengighet beskrives i artikkelen. Den epidemiologiske forskningen om andre rusmidlers sammenheng med vold er betydelig mindre omfattende enn den er for alkohol. Det er også åpenbart at andre rusmidler ikke er like sterkt sammenknyttet med vold som alkoholen.
\end{abstract}

Pernanen K. Alcohol, other drugs, and violence in an epidemiological perspective. Nor J Epidemiol 1996; 6 (1): 29-36.

\section{ENGLISH SUMMARY}

The public health approach to violence has become increasingly accepted during the last couple of decades. This has led to more epidemiological research into violence, and a stronger medical interest in the etiology and prevention of violence. However, epidemiological research on the prevalence of violence in different societies is still mainly criminological in nature, being based on information about violence that has come to the attention of the police or processed in the courts. The study of the relationship between alcohol use and violent behaviour is also predominantly based on police and court materials, although an increasing number of emergency room and hospitalization studies have examined the role of alcohol in injuries caused by violence.

There are two basic methodological approaches in the study of the relationship between alcohol use and violence. The alcohol-involvement studies estimate the extent to which drinking by the offender or the victim was present in episodes of violence. Time trend studies and so-called natural experiments measure how rates of violent crime covary with levels of alcohol consumption in a population. Generally, these studies indicate that alcohol use is a potent factor in determining the prevalence of violent behaviour in a society. However, there is no evidence showing that a significant part of alcohol-related violence is directly caused by the presence of alcohol in the organism. Four types of conditional factors affecting the risk of violent behaviour after drinking are discussed: (1) the nature of the alcohol factor, (2) characteristics of the individual drinker, (3) the socio-cultural context in which drinking occurs, and (4) situational factors.

The epidemiological evidence for a relationship between violence and the use of other drugs is much more scattered. It is complicated by the fact that most drug users use more than one type of drug. When an illegal psychoactive drug is implicated in violent behaviour, it is often also accompanied by alcohol use. Clinical and experimental evidence shows that the risk of aggression and physical violence depends, in addition to the type of drug, on the amounts used, the method of application, the phase of acute intoxication, and the long-term pattern of use. However, the violence associated with the use of illegal drugs is perhaps most closely determined by the characteristics of an illegal economy. Rival criminal organizations manufacture, distribute and sell these drugs, and they use violence and threats as a means of regulating this economy. In addition, many drug users resort to violent crime in an effort to secure the funds needed for their addiction. 


\section{DET EPIDEMIOLOGISKE PERSPEKTIVET PÅ VOLD}

Innenfor det medisinske faget har man til alle tider måttet håndtere følgene av volden $\mathrm{i}$ form av skader og død. I motsetning til vanlige sykdomstilstander har imidlertid den medisinske forskningen tidligere ikke fokusert særlig på å utforske årsakene til volden, og heller ikke anlagt en preventiv synsmåte på volden. Denne innstillingen er forandret i løpet av de seneste to tiårene, og man har begynt å legge an både epidemiologiske metoder og sosialmedisinske preventive synspunkter på voldsproblematikken (1). Denne utviklingen er særlig sterk i USA. Blant annet er det der blitt grunnlagt en egen avdeling for voldsforskning innen det amerikanske Centers for Disease Control, og legene i USA kan nå for eksempel spesialisere seg innenfor faget familievold. Men også i de nordiske landene og i det øvrige Europa har folkehelseperspektivet på vold blitt mer akseptert.

Volden rammer mest unge mennesker, og de kan som følge av grov vold få hele livet ødelagt. I nasjonal- og helseøkonomiske termer betyr dette at samfunnet taper mye $\mathrm{i}$ form av manglende produktivitet og kostbar omsorg over lange perioder. Ifølge norske beregninger er de årlige utgiftene for voldsskader på sykehus ca. 97 millioner kroner. Justis- og fengselskostnader for voldsutøvere er også betydelige. I tillegg kommer den psykiske og fysiske lidelsen og den redsel som mange i samfunnet lever med på grunn av volden. Den velkjente epidemiologen James Last har også sagt at sammen med miljøproblemene er volden den store utfordringen innenfor folkehelsen i vår tid (2).

Tradisjonelt er volden et kriminologisk spørsmål og en stor del av forskningen omkring vold er skjedd innenfor dette faget. Av delvis strafferettslige årsaker er det også viktig å undersøke om voldsutøveren kan anses for å ha vært ansvarlig for sine handlinger på tidspunktet for voldshendelsen. Dermed er psykiatri og deler av psykologien sentrale fag i forskningen om vold. Mye forskning som kan hjelpe oss å oppdage de kausale mekanismene bak volden skjer innenfor biologi og genetikk, tildels for å finne ut om det finnes en genetisk grunn til at visse individer er mer voldsomme enn andre. Annen forskning finner sted innenfor klinisk og eksperimentell psykologi for å kartlegge hva slags personlighetstrekk og situasjoner som gir en forhøyet risiko for at aggressiv atferd skal finne sted. Voldsforskning er i aller høyeste grad et tverrvitenskapelig felt (3). Dersom volden er et almenmenneskelig problem, er denne forskningen også et meget internasjonalt felt.

\section{VOLDSNIVÅER I NORGE OG ANDRE STEDER}

Det statistikkførte voldsnivået viser store forskjeller mellom ulike land. Norge har et voldsnivå som med hensyn til drap ligger langt under det amerikanske nivået. Drapsratene er omtrent ti ganger høyere i USA enn i Norge. En stor forskjell finnes også med hensyn til kjent vold som ikke har ført til døden. Når man sammenligner voldsnivået i Norge med nivået i Sverige, Finland og Danmark viser det seg at Norge sammen med Danmark har den laveste frekvensen drapstilfeller. Med hensyn til voldsforbrytelser (legemsfornærmelse og legemsbeskadigelse) har Danmark tradisjonelt hatt den laveste frekvensen med Norge på nest laveste plass. Finland og Sverige har betydelig høyere tall.

Den norske voldsforbrytelsesutviklingen viser dog en stigende trend og vekker en betydelig uro i landet. Man kan imidlertid ikke stole utelukkende på den offentlige statistikken og forandringer i denne. Olaussen (4) har sammenlignet den norske kriminalstatistikken med spørreundersøkelser om utsatthet for vold i den alminnelige populasjonen (såkalte offerundersøkelser) og konkluderer at "alle data tyder på at voldskriminaliteten var stigende i 1970-årene, og tiåret etter har vært preget av et langt mer stabilt omfang av vold enn Kriminalstatistikken umiddelbart kan gi inntrykk av" (s. 113, forfatterens kursivering). Når det gjelder begynnelsen av 1990-tallet viser Kriminalstatistikken en tydelig økning for både anmeldte og etterforskede voldsforbrytelser (5). Et svar på spørsmålet om hvorvidt disse økningene gjenspeiler en økning i det virkelige voldsnivået krever imidlertid ytterligere forskning.

Dersom bare en mindre del av volden som skjer i samfunnet blir kjent av politiet gjør man i mange land spesielle undersøkelser der man spør utvalg av befolkningen om deres erfaringer med vold. I slike offerundersøkelser fra årene 1989 og 1991 sammenlignet man 20 land fra ulike deler av verden (6). Man fant at $3,0 \%$ av den norske befolkningen hadde blitt offer for legemsfornærmelse, legemsbeskadigelse eller trussel om slik vold i løpet av en 12-måneders periode. Gjennomsnittet for de 20 landene var eksakt det samme: $3,0 \%$. For de 15 europeiske landene som deltok var gjennomsnittet noe lavere $(2,6 \%)$. Av de nordiske landene som deltok hadde Sverige et prevalenstall på 2,7\% og Finland 3.5\%. Disse tallene passer vel inn med funn fra andre offerundersøkelser i Norden på dette tidspunktet (7).

\section{ALKOHOL OG VOLD}

Alle de faktorer som innvirker på risikoen for vold i samfunnet er av medisinsk, kriminologisk, samfunnsvitenskapelig og politisk interesse. Det er følgelig viktig å finne ut hvilke faktorer som forhøyer risikoen for vold, og som kan gi holdepunkter for hensiktsmessige tiltak for å senke voldsnivået. Alkoholen er en slik risikoforhøyende faktor. Det har i lange tider vært kjent i ulike land at alkoholen har en evne til å høyne 
menneskers (eller i det minste menns) tendens til å oppføre seg på en aggressiv måte, og dette er gjenspeilt i ord og uttrykk i hverdagsspråket. Det har også blitt funnet i flere spørreundersøkelser at folk flest mener at alkohol kan gjøre mennesker aggressive.

\section{Epidemiologiske funn}

Voldsforbrytelsens epidemiologi finnes vel kartlagt gjennom statistisk informasjon som publiseres rutinemessig. Denne informasjonen bygger i hovedsak på anmeldelser som politiet får av vold som har skjedd $\mathrm{i}$ samfunnet, samt på informasjon om voldssaker i domstolene. Derimot finnes naturligvis ikke mange av de faktorer som har vist seg å være knyttet til vold med i slike statistikkserier. Man mangler også i de aller fleste land statistiske opplysninger om alkoholens tilstedeværelse i voldshendelser. Man må derfor gjennomføre særlige undersøkelser for å finne dette ut.

Det finnes hovedsakelig to typer av undersøkelser innenfor den alkoholrelaterte voldens epidemiologi. Den første er basert på informasjon om alkoholens nærvær i enkelte tilfeller av vold, mens den andre sammenligner generelle trender $\mathrm{i}$ utviklingen av voldstilfeller (uansett om disse var alkoholrelaterte eller ikke) med trender i utviklingen av det gjennomsnittlige volumet av alkohol som er konsumert innenfor samme populasjon.

1. Studier av alkoholens andeler $i$ voldsforbrytelser forsøker å finne ut i hvor stor andel av kjente voldsepisoder som voldsmannen eller offeret eller begge hadde drukket før volden brøt ut. De bygger i hovedsak på materiale over vold som er kommet til politiets kjennskap, men voldstilfeller som er behandlet i domstolene, er også blitt brukt i mange undersøkelser. Slike undersøkelser har blitt gjort i atskillige land. Samlet viser de at både gjerningsmenn og ofre har vært påvirket av alkohol i en stor andel av tilfellene av legemsfornærmelse, legemsbeskadigelse og drap, enten de er utført i de nordiske land, andre europeiske land, Nordamerika, noen afrikanske land eller Grønland. Norske undersøkelser viser oftest tall mellom 60 og 75 prosent for gjerningsmenn og omtrent like mye for voldsofre $(8,9,10)$. Forskjellen fra Sverige og Finland er ikke stor. De høyeste tallene er funnet for Grønland, der over $80 \%$ av de drapssiktede hadde drukket alkohol før drapshendelsen.

Studiene av alkoholens nærvær i andre slags voldsforbrytelser, først og fremst ran og voldtekter, er ikke like mange. Resultatene viser en større variasjon i denne andelen enn for de ovenfor nevnte voldsforbrytelsene. Man har funnet at alt fra 7\% til 72\% av ranerne var påvirket av alkohol og nesten like varierende tall for ofrene (11). Roizens sammenligning viser alkoholandeler blant seksualforbrytere på mellom $13 \%$ og $60 \%$, mens sifrene for ofrene varierer mellom $6 \%$ og 40\% (11). Tildels må forskjellene skyldes lokale variasjoner med hensyn til alkohol- og voldskulturer og frekvensen av anledninger til ran, voldtekter og andre seksualforbrytelser. Noen undersøkelser fra tidligere år indikerer at gjerningsmenn $\mathrm{i}$ både ran og voldtekter har drukket alkohol før forbrytelsen i stor utstrekning også i Norge (9).

Alkoholens andel av voldshendelser $\mathrm{i}$ andre populasjoner av voldsofre enn de som blir kjent av politiet har blitt undersøkt. Spesielle utvalg har blitt gjort med kvinner som er kommet til kvinnesentre eller akuttmottakelse etter å ha blitt utsatt for vold av sine ektemenn eller samboer. Disse peker på at en stor andel av mennene, men også en anselig andel av kvinnene, hadde drukket alkohol før voldshendelsen.

En del studier av alkoholens andel $i$ voldsskader er også blitt gjort. I en rekke undersøkelser har man studert de voldstilfeller som blir kjent på akuttmottakelser eller på sykehus. For disse pasienter har man observert eller spurt om alkoholforbruk forut for voldshendelsen $(12,13)$. Man finner stadig i disse undersøkelsene at alkohol har blitt drukket $\mathrm{i}$ en stor andel av voldstilfeller.

Et viktig spørsmål er om den alkoholrelaterte volden er grovere enn den edru volden og om volden $i$ sammenheng med høyere beruselsesgrad er grovere enn den som skjer når gjerningsmannen og/eller offeret er mindre beruset. De få undersøkelser som har blitt gjort omkring disse spørsmålene indikerer at den alkoholrelaterte volden er noe grovere. Tildels kan dette bero på alkoholens parestetiske effekter, som gjør at voldsdeltakerne ikke kjenner smerte i samme utstrekning som edru voldsdeltakere. Flere undersøkelser viser også at voldsofre som har drukket, har meget høye alkoholverdier - i noen undersøkelser over 2 promille i gjennomsnitt $(14,15)$. Dette kan bety at ofrene i mange tilfeller ikke har nødvendig evne til å forlate voldssituasjonen før de blir skadet. Voldsskader under alkoholrus blir kanskje heller ikke lagt merke til like tidlig og lege kontaktet like raskt som tilfellet er med vold der ofret er edru.

Svært lite data eksisterer med hensyn til alkoholens rolle i vold som ikke er kommet til myndighetenes eller til helsetjenestens kjennskap. Undersøkelser har blitt gjort omkring familievold, og disse har funnet at denne volden, som i stor grad er skjult for myndigheter og andre, ofte har alkohol som bakgrunn på en eller annen måte (16). Dessuten finnes flere undersøkelser over ungdomsvold, spesielt mobbing. Det er dog grunn til å tro at mobbing egentlig har lite å gjøre med alkoholkonsum. Derimot er det alkoholkonsumet som skjer blant 15-16 åringer og eldre ungdom ofte sammenkoblet med almen aggressivitet og vold. Skretting (17) fant at $9 \%$ av norske 9. klassinger hadde vært i slagsmål på grunn av at de hadde drukket alkohol. Omtrent en fjerdepart sa at de hadde kranglet av samme årsak.

I den internasjonale litteraturen har i det minste en undersøkelse sett på voldshendelser $i$ alminnelige befolkninger som ikke nødvendigvis har kommet til 
politiets kjennskap. I denne spørreundersøkelsen sammenlignes en by i Canada med en by i Sverige og man fant at alkoholen var tilstede i nesten samme utstrekning (55-60\%) som i politianmeldelser av voldsforbrytelser $(18,19)$. Omtrent en fjerdedel av disse hendelsene endte med fysiske skader og en av seks ble kjent av politiet. I det hele tatt var disse hendelsene av mildere karakter enn de som blir statistikkført av politiet, men også her var alkoholens andel betydelig.

2. Den andre hovedtypen av epidemiologiske metoder for å undersøke om det finnes en sammenheng mellom alkoholforbruk og den vold som skjer $i$ samfunnet er å sammenligne utviklingen over tid mellom alkoholkonsum og vold. I praksis har de fleste av disse studiene brukt informasjon om vold som er kommet til politiets kunnskap som mål på voldsnivået, mens noen få har benyttet data vedrørende fysiske voldsskader som har kommet til akuttmottakelse eller sykehus.

Det finnes to undertyper av disse studiene. (Også andre er mulige, men har ikke blitt prøvd i empiriske studier.) Den kanskje enkleste av de to er de "naturlige eksperimentene". I disse situasjonene endres tilgangen på alkohol drastisk på grunn av en streik, en endring i alkoholloven med hensyn til lovlig alder, eller at salg av en eller annen type alkohol begynner $i$ dagligvarebutikker, at man stenger alkoholbutikkene visse dager i uken (f.eks. lørdager), osv. Man kan da se om endringer i tilgang går sammen med anmeldelser over ulike voldsforbrytelser som politiet får kjennskap til, eller tilfeller av fysiske voldsskader som kommer til helsetjenesten.

I de aller fleste studier av denne typen har man funnet at når tilgangen på alkohol blir mindre, synker også voldsnivået. Et av de få unntakene er den streiken som rammet det norske vinmonopolet i 1978 (20). Det bør dog bemerkes at tilgangen på alkohol i praksis aldri blir null. Man kan derfor ikke uten videre se hvor stor andel av volden som kunne vært forårsaket av tilbudet på alkohol. I sammenheng med streiker som påvirker butikksalget av alkohol er skjenkesteder ofte åpne, det finnes gode muligheter til hamstring etter at streiken er varslet, hjemmebrenning og smugling skjer i økt omfang etter en tid med mangel på alkoholholdige drikkevarer, osv. Horverak (21) beregnet at ved streiken i 1978 sank det totale konsumet bare med 5-10\%.

Den andre metoden med sammenligninger over tid er egentlig en mer almen form av de "naturlige eksperimentene". I disse tidstrendstudiene følger man variasjoner $\mathrm{i}$ alkoholkonsum over lengre tid og måler om disse samvarierer med voldshendelsenes hyppighet. I de nordiske landene finnes statistikkserier som trekker seg langt tilbake $\mathrm{i}$ tid både med hensyn til alkoholkonsum og voldsforbrytelser. Analyser av slik informasjon indikerer at det finnes en sammenheng mellom endringer $\mathrm{i}$ totalkonsumet og endringer $\mathrm{i}$ nivået av voldsforbrytelser. Skog og Bjørk (22) fant at dette var tilfelle i Norge. De to fenomenene er imidlertid sammenknyttet i ulik grad i ulike land. Lenke (23) fant $i$ sin studie at f.eks. de finske voldstallene var tre ganger så sterkt forbundet med konsumentnivået som de franske. For Norge var denne sammenhengen nærmere den finske enn den franske.

\section{Risikookende faktorer for alkoholrelatert vold}

Det finnes mange teorier om hvorfor alkoholen generelt sett øker risikoen for vold. Det er trolig at mange av disse forklarer sin egen del av den alkoholrelaterte volden og at vi derfor ikke vil finne en enkelt sann teori. Det eksisterer dog stor usikkerhet om hvor stor del av den alkoholrelaterte volden disse ulike teorier $i$ virkeligheten forklarer. En teoretisk ekskursjon ville ta opp for mye plass, og jeg skal her bare ta opp de typer faktorer som må tas i betraktning i en forholdsvis fullstendig forklaring av den alkoholrelaterte volden.

I lys av de funn som har blitt gjort om sammenhengen mellom alkohol og vold på det epidemiologiske plan, synes det naturlig å anta at alkoholen i seg selv er en tilstrekkelig årsak til at vold kan skje, og visse teorier har også bygd på en slik antagelse. Man har f.eks. antatt at alkoholen først angriper hjernens "høyere" sentre og at de lavere sentra følgelig blir de som bestemmer den alkoholberusedes handlinger. Slike teorier er ofte sammenkoblet med antagelsen om at personens inhiberte aggressive tendenser på denne måten blir "disinhiberte". Det finnes imidlertid ikke noen vitenskapelige funn som tyder på at alkoholen forårsaker en slik hjernefysiologisk prosess. Både hverdagsobservasjoner og systematisk forskning av atferd under alkoholpåvirkning peker også på at det ikke finnes en direkte sammenheng mellom alkoholinntak og aggressiv atferd. Isteden finnes et antall ulike omstendigheter som må være tilfredsstilt, før risikoen for alkoholrelatert vold blir betydelig forhøyet (24). Disse omstendighetene kan deles inn i fire grupper avhengig av ulike aspekter innenfor drikkeepisoden:

1. Den første av disse fire omstendighetene er den mest åpenbare. Den glemmes imidlertid hyppig bort $\mathrm{i}$ de teoretiske diskusjonene omkring alkoholrelatert vold. Dette er alkoholkonsumets karakter.

Man må ta hensyn til flere ulike egenskaper ved alkoholen når man prøver å forklare alkoholpåvirket atferd. Eksperimentelle undersøkelser viser i det hele tatt at en økning i aggressiv atferd skjer med et høyere nivå alkohol i organismen (25). Det finnes naturligvis en øvre grense av beruselse for når en alkoholkonsument er i stand til å bruke vold mot en annen person. Alkoholtype (øl, vin, sterksprit eller annet) og (delvis avhengig av drikketype) mengden av fremmede substanser i drikken har blitt foreslått som aspekter på alkoholbruk som kan påvirke risikoen for aggressiv 
atferd. De få eksperimentelle undersøkelser som har blitt gjort, har likevel ikke utvetydig vist at disse kjemiske faktorene har særlig stor betydning. De forskjeller man har funnet mellom ulike alkoholtyper er sannsynligvis like mye avhengig av de psykologiske forventningene som er knyttet til ulike drikker og visse egenskaper hos de personer som foretrekker ulike alkoholsorter (f.eks. kjønn).

Svært lite er kjent om hvordan risikoen for aggressiv atferd er påvirket av den drikkefase som personen befinner seg i. Noen funn fra eksperimentell forskning indikerer at forsøkspersoner er mer irritable $\mathrm{i}$ den nedovergående fasen av alkoholberuselse enn i den oppovergående fasen, men spørsmålet har ikke vært gjenstand for tilstrekkelig vitenskapelig oppmerksomhet. Det samme gjelder spørsmålet om manglende næringsinntak sammen med alkoholkonsum, som jo er spesielt hyppig blant alkoholmisbrukere. Dette leder til mangel på blodsukker som i seg selv, og sannsynligvis ytterligere sammen med alkoholens virkninger, kan forhøye risikoen for irritabilitet og aggressiv atferd. Ennå mindre vet vi om den virkning som mangel på søvn, særlig den viktige REM-søvnen, kan ha for voldsatferd i langvarige drikkesituasjoner. (Denne søvnbristen har av noen forskere blitt fremsatt som en sentral årsak til delirium tremens.)

2. Den andre typen av omstendighet er knyttet til det enkelte individ. Allerede usystematiske observasjoner av andre konsumenter i drikkesituasjoner har lært mange av oss at ulike mennesker reagerer på svart forskjellige måter etter at de har drukket alkohol. Denne observasjonen har også funnet støtte i eksperimentelle og kliniske undersøkelser. Blant de biologiske faktorer som ligger bak dette, har man foreslått genetisk bestemt serotoninnivå (26), men dette kan delvis være bundet til en høyere disponerthet for blodsukkerbrist.

En viktig forskjell er naturligvis den mellom menn og kvinner. Fra epidemiologiske undersøkelser er det kjent at kvinner begår en svært liten del av volden i samfunnet, omtrent $5-10 \%$ av volden som blir kjent av politiet. Det er også funnet i noen eksperimentelle undersøkelser at kvinner ikke får samme aggresjonsforhøyende effekt av alkoholkonsum som menn. I mine egne undersøkelser i Canada fant jeg at kvinner faktisk oftere blir sinte i alkoholbrukssituasjoner, til dels på grunn av den atferd som menn viser i slike situasjoner. Derimot reagerer de med fysisk vold mye sjeldnere enn menn selv om de er sinte når de har drukket (27). Slike kjønnsrelaterte sammenhenger kan dog variere mellom ulike samfunn.

3. Forskjellen mellom kvinner og menn med hensyn til alkoholrelatert vold er sannsynligvis også, i det minste til dels, avhengig av sosiokulturelle faktorer, særlig de kjønnsroller som gjelder i et samfunn. I sosialantropologiske studier har man funnet at voldsnivået $\mathrm{i}$ alkoholbrukssituasjoner varierer mye mellom ulike førindustrielle samfunn $(28,29)$. Disse forskjel- lene synes i det store og hele å være uavhengig av de mengder og typer alkohol som er konsumert. Det ble også nevnt ovenfor at Lenke (23) i sin studie av flere europeiske land fant store forskjeller i hvilken grad voldsnivået innenfor de enkelte land var avhengig av skiftninger i alkoholkonsumets nivå. Foruten strukturelle forskjeller mellom ulike samfunn, som drikkesort, drikkesteder, konsumerte mengder i en drikkesituasjon m.m., finnes atskillige forskjeller i sosiale og individuelle funksjoner som alkoholen tilfredsstiller, holdninger til alkoholen, osv. Man har også funnet at forventninger med hensyn til alkoholens virkninger påvirker menneskers atferd i drikkesituasjoner (30). Disse forventningene er forskjellige i ulike samfunn. Alle disse faktorene påvirker risikoen for at vold skal opptre i en alkoholbrukssituasjon.

4. Svært få mennesker blir voldsomme helt uavhengig av hva som skjer $i$ deres omgivelser. Dette gjelder også etter at de har drukket alkohol. I eksperimentelle undersøkelser har man funnet at skuffelser, frustrasjoner, provokasjoner og liknende forhold øker risikoen for aggressiv atferd etter alkoholkonsumering mer enn når man er edru. Disse studiene indikerer også at alkoholen i seg selv, uavhengig av hva som skjer i situasjonen, ikke har noen forsterkende virkning på risikoen for aggressiv atferd.

\section{Voldens sammenheng med langvarig overkonsum av alkohol}

Hittil har vi vært opptatt av å behandle sammenhengen mellom akutt alkoholpåvirkning og vold. Det finnes dog andre viktige koblinger mellom alkohol og aggressive og voldsomme handlinger. Alkoholen kan sies å være en "konfliktskaper", særlig innenfor visse familier. Alkoholbruk koster penger, tar opp fritid og leder til at det normale samværet og kommunikasjonen mellom familiens medlemmer blir forstyrret. Overdreven alkoholbruk er også stigmatiserende og skader familiens anseelse overfor slektninger og naboer. Slike faktorer påvirker det saklige og emosjonelle miljøet i mange familier og leder til en forhøyet risiko for konflikter som blir forverret av alkoholens mer akutte virkninger. En hel del finnes publisert omkring denne problematikken, men rammene for denne artikkelen rekker ikke til for å gå inn på denne litteraturen. En omfattende litteratur behandler også de organiske hjerneskader som langvarig alkoholmisbruk kan forårsake og som kan ha en sammenheng med en forhøyet risiko for alkoholrelatert vold (31).

\section{ANDRE RUSMIDLER OG VOLD}

Epidemiologiske funn viser at alkoholen er den store aktøren i voldssituasjoner i mange land. Til tross for dette er folk flest på mange steder overbevist om at andre rusmidler har en større andel i volden enn alkohol har. Til dels kan dette skyldes at massemediene 
fokuserer på narkotikaproblematikken i mye større grad enn på alkoholen.

Det finnes svært få data om hvor stor rolle andre rusmidler enn alkohol egentlig spiller i kjente voldsforbrytelser. Ifølge Bødals (8) analyser av norske rettsdokumenter vedrørende 250 personer som ble dømt for drap eller drapsforsøk i perioden 1980-89 hadde meget få gjerningsmenn inntatt bare andre stoffer enn alkohol før voldssituasjonen. Når andre rusmidler hadde blitt brukt, skjedde det vanligvis i tillegg til alkoholinntak. Fekjær (9) rapporterer også at siktede i voldsforbrytelser i Norge fra årene 197677 hadde brukt andre rusmidler enn alkohol i meget liten utstrekning.

I motsetning til alkoholens sentrale rolle finner man også i den internasjonale voldsforskningen nærmest forbausende lite illegal stoffbruk blant de involverte i kjente voldssaker. Dette gjelder også i en viss utstrekning de store byene i USA, der narkotikamisbruket er mye mer utbredt enn i de nordiske landene $(14,32)$. Det er imidlertid vanskelig på grunnlag av epidemiologiske data å si mye om hvordan bruk av andre rusmidler enn alkohol henger sammen med vold, dersom brukerne av disse stoffene i stor utstrekning benytter mer enn et slags rusmiddel tett innpå hverandre, deriblant også alkohol (33). I USA, der jo narkotikabruk er svært utbredt blant unge mennesker som lever i omstendigheter med forhøyet risiko for å begå kriminelle handlinger, har man imidlertid estimert at omtrent 10 prosent av alle drap var relaterte til bruk av andre rusmidler enn alkohol (34).

Det finnes eksperimentelle undersøkelser som sammenligner alkoholens og andre rusmidlers innvirkning på aggressive handlinger. F.eks. sammenlignet Taylor og hans medarbeidere cannabis (tetrahydrocannabinol) og alkohol (35). De fant at mens alkohol på visse situasjonelle betingelser økte tendensen til aggressiv atferd gjorde ikke cannabis det samme. Tinklenberg og hans medarbeidere (36) fant $\mathrm{i}$ en epidemiologisk studie blant insatte $\mathrm{i}$ ungdomsfengsel at alkoholforbruk var sammenkoblet med voldsforbrytelser i mye større grad enn cannabisbruk. Noen andre forskere har trukket samme konklusjon ved epidemiologiske studier av voldshendelser.

Når det gjelder de ulike rusmidlene, varierer naturligvis de farmakologiske effektene svært mye. Også cannabis i ulike konsentrasjoner (slik som i hasjisj og marihuana, fra varierende arter og forskjellige dyrkesteder) kan ha ulike effekter. De neurobiologiske virkningene av ulike psykoaktive rusmidler varierer også avhengig av mengden som brukes, fasen av akutt påvirkning og de langvarige forbruksmønstrene. Ingen av de vanligste illegale stoffene har en særlig og direkte aggresjonsforhøyende effekt. De prosesser som forbinder den akutte bruken av et og samme rusmiddel med voldsatferd, kan være meget forskjellige. Høye doser av et stoff kan lede til forvirring med en slags defensiv aggression som følge. Dette gjelder blant annet amfetaminer, kokain og LSD. Psykotiske og paranoide episoder kan forekomme som følge av langvarig bruk av kokain og amfetamin. Visse rusmidler (f.eks. LSD) kan forsterke risikoen for vold blant personer med tidligere psykopatologiske forstyrrelser. Kronisk bruk av de fleste droger minsker, gjennom virkningene på det sentrale nervesystemet, evnen til sosial kommunikasjon, særlig i stressede situasjoner. Dette leder ofte til en forhøyet risiko for konflikter med omgivelsene. Abstinensfasen blant opiatavhengige personer kan, om man kan generalisere fra dyreeksperiment og kliniske observasjoner, lede til aggressive handlinger. På den annen side kan lavere doser av f.eks. marihuana og opiater lede til en forminsket risiko for aggressiv atferd.

Det finnes flere studier, mest av klinisk art, som peker på at anabole steroider har farmakologiske effekter som kan øke risikoen for aggressiv atferd. Spesielt voldsfrembringende blir denne virkningen når bruken av disse stoffene skjer sammen med alkoholforbruk. Samme slags risikoøkning synes å oppstå når amfetamin brukes sammen med alkohol.

Det er allment akseptert at en av de viktigste grunnene til vold i forbindelse med ulike slags illegale rusmidler er de økonomiske motivene (37). Den økonomiske virkeligheten som omgir både fremstilling, distribusjon og bruk av illegale stoffer leder til konflikter og vold mellom brukere og mellom og innenfor organiserte kriminelle grupper. Illegale stoffer er dyre, og den som er avhengig av disse må i noen tilfeller finansiere sitt forbruk ved vinningsforbrytelser som er knyttet til vold (38). Den økonomisk motiverte volden vokste også i de vestlige land hvor man prøvde forbud mot fremstilling og forbruk av alkoholholdige drikker. Det oppstod snart en illegal handel som for det meste ble regulert, ikke gjennom lov, men gjennom vold og trusler. Oppgjør mellom ulike ligaer som fremstiller, formidler og selger heroin, kokain, amfetamin og andre illegale stoffer krever hvert år et stort antall døde og skadede individer i mange land.

\section{SLUTTORD}

Volden i samfunnet har negative virkninger i tillegg til de skader, lidelser og ubehageligheter som kommer voldsoffer, voldsmenn og deres pårørende til del. Til voldens videre effekter hører blant annet redselen som oppstår til og med blant dem som aldri har blitt utsatt for grove voldshandlinger (39). En annen indirekte og langvarig virkning er den trusselen som voldshandlinger innebærer for den normative grunnen for samfunnet. Samfunnet er bygget opp på ett nettverk av normer, av hvilke noen er kodifisert i landets lovsamlinger. Alle disse normer kan kullkastes med vold, og denne blir derfor opplevd som en trussel mot samfunnets bestående. I den utstrekning som alkoholen og andre rusmidler er del i volden er de også del i uroen som volden er opphav til. 


\section{REFERANSER}

1. Rosenberg ML, Gelles RJ, Holinger PC, Zahn MA, Stark E, Conn JM, Fajman NN, Karlson TA. Violence: Homicide, Assault and Suicide. I: Amler RW, Dull HB, red. Closing the gap: The burden of unnecessary illness. New York: Oxford University Press, 1987.

2. Last J. The two highest priorities in public health (Editorial). Can J Public Health 1986; 77: 5-6.

3. Pernanen K. Research approaches in the study of alcohol-related violence. Alcohol Health Res World 1993; 17: 101-7.

4. Olaussen LP. Voldskriminalitetens utvikling i Norge de to siste tiårene. Nordisk Tidsskrift for Kriminalvidenskab 1995; 82: 97-116.

5. Statistisk sentralbyrå. Kriminalstatistikk 1993. Oslo-Kongsvinger: Statistisk sentralbyrå, 1995.

6. del Frate AA, Zvekic U, van Dijk JJM. Understanding crime: Experiences of crime and crime control. Rome: United Nations Interregional Crime and Justice Research Institute, 1993.

7. Vogel J. Leva i Norden. Levnadsnivå och ojämlikhet vid slutet av 80-talet. København: Nordisk Statistisk Skriftserie 54, 1990.

8. Bødal K, Fridhov IM. Det gjelder drap. Oslo: Kriminalomsorgens utdanningssenter, 1995.

9. Fekjær HO. Alkohol og vold. I: Laake H, red. Alkohol og vold - årsaker og virkninger. Stavanger: Universitetsforlaget, 1985.

10. Olaussen LP. Beruselse, utelivsdeltakelse og utsatthet for vold. PHS Forskning 1995:3. Oslo: Politihøgskolen, 1995.

11. Roizen J. Issues in the epidemiology of alcohol and violence. I: Martin S, red. Alcohol and interpersonal violence: Fostering multidisciplinary perspectives. National Institutes of Health, National Institute of Alcohol Abuse and Alcoholism, Research Monograph No. 24. Washington, D.C.: U.S. Department of Health and Human Services, 1993.

12. Reigstad A, Bredesen JE, Lunde PKM. Ulykker, alkohol og nervemedisin. Forekomst og samvariasjon. Oslo: Universitetsforlaget, 1977.

13. Bang L. Forprosjekt: Handlingsplan mod seksuelle overgreb, seksualiseret vold og prostitusjon, med utgangspunkt i Helsetjeneste for voldsrammede. Oslo: Akuttetaten, 1993.

14. Goodman RA, Mercy JA, Loya F, Rosenberg ML, Smith JC, Allen NH, Vargas L, Kolts R. Alcohol use and interpersonal violence: Alcohol detected in homicide victims. Am J Public Health 1986; 76: 144-149.

15. Virkkunen M. Alcohol as a factor precipitating aggression and conflict behavior leading to homicide. $\mathrm{Br} J$ Addict 1974; 69: 149-154.

16. Malterud K. Mishandlede kvinners skadesmønster og livssituation. Tidsskr Nor Laegeforen 1982; 33: 17871790.

17. Skretting A. Bruk av tobakk, alkohol og narkotika blant norske 9. klassinger. Oslo: Statens institutt for alkohol- og narkotikaforskning, Rapport Nr. 1/96, 1996.

18. Pernanen K, Carsjö K. Våld och dess samband med alkoholbruk - en jämförande internationell undersökning. CAN Forskningsnytt 1987; 8: 8-12.

19. Pernanen K. Alcohol in human violence. New York: Guilford Press, 1991.

20. Hauge R. Kriminalitetsutviklingen under streiken. I: Horverak Ø, Nordlund S, red. Da Vinmonopolet stengte. Oslo: Universitetsforlaget, 1983.

21. Horverak Ø. Alkoholkonsumet under streiken. I: Horverak Ø, Nordlund S, red. Da Vinmonopolet stengte. Oslo: Universitetsforlaget, 1983.

22. Skog O-J, Bjørk E. Alkohol og voldskriminalitet. En analyse av utviklingen i Norge 1931-1982. Nordisk Tidsskrift for Kriminalvidenskab 1988; 75: 1-23.

23. Lenke L. Alcohol and criminal violence. Stockholm: Almqvist \& Wiksell International, 1990.

24. Pernanen K. Sambandet alkohol-vold: en oversikt. Oslo: Statens institutt for alkohol- og narkotikaforskning, 1996.

25. Bushman BJ, Cooper HM. Effects of alcohol on human aggression: An integrative research review. Psychol Bull 1990; 107: 341-354.

26. Linnoila M, Virkkunen M, Scheinin M, Nuutila A, Rimon R, Goodwin FK. Low cerebrospinal fluid 5hydroxyindoleacetic acid concentration differentiates impulsive from nonimpulsive violent behavior. Life Sci 1983; 33: 2609-14. 
27. Pernanen K. Conflict, anger and aggression: The role of alcohol. New York: Plenum Press (under trykking), 1996.

28. MacAndrew C, Edgerton RB. Drunken comportment. Chicago: Aldine, 1969.

29. Marshall M. "Four hundred rabbits": An anthropological view of ethanol as a disinhibitor. I: Room R, Collins G, red. Alcohol and disinhibition: Nature and meaning of the link. Rockville, MD: U.S. Department of Health and Human Services, U.S. Government Printing Office, 1983.

30. Lang AR, Sibrel PA. Psychological perspectives on alcohol consumption and interpersonal aggression: The potential role of individual differences in alcohol-related criminal violence. Criminal Justice Behav 1989; 16: 299-324.

31. Løberg T. Belligerence in alcohol dependence. Scand J Psychol 1983; 24: 285-92.

32. Haberman PW, Baden MM. Alcohol, other drugs and violent death. New York: Oxford University Press, 1978.

33. Reiss AJ, Roth A, red. Understanding and preventing violence. Washington, D.C.: National Academy Press, 1993.

34. Harwood H, Napolitano D, Kristiansen P, Collins J. Economic costs to society of alcohol and drug abuse and mental illness. Final report. Washington, D.C.: Alcohol, Drug Abuse and Mental Health Administration, 1984.

35. Taylor SP, Vardaris RM, Rawtich AB, Gammon CB, Cranston JW, Lubetkin AI. The effects of alcohol and delta-9-tetrahydrocannabinol on human physical aggression. Aggressive Behav 1976; 2: 153-161.

36. Tinklenberg JR, Roth WT, Kopell BS, Murphy P. Cannabis and alcohol effects on assaultiveness in adolescent delinquents. Ann N Y Acad Sci 1976; 28: 85-94.

37. Brochu S. Analyse de la délinquance des consommateurs de drogues illicites. Université de Montréal: Centre international de criminologie comparée, 1995.

38. Collins JJ, Hubbard R, Rachal V. Expensive drug use and illegal income: A test of explanatory hypotheses. Criminology 1985; 23: 743-764.

39. Olaussen LP. Angst for voldskriminalitet i Norge. Nordisk Tidsskrift for Kriminalvidenskab 1995; 82: 249-72. 